\title{
Analysis of the Dynamics of Inflation Rate in Romania and Euro Area
}

\section{Ramona Mariana CALINICA ${ }^{\star}$}

\begin{tabular}{l}
\hline \multicolumn{1}{c}{ A R T I C L E I N F O } \\
\hline Article history: \\
Accepted August 2020 \\
Available online August 2020 \\
\hline JEL Classification \\
E52 \\
Keywords: \\
Inflation rate, Monetary policy, \\
Euro Area
\end{tabular}

\begin{abstract}
A B S T R A C T
Inflation is an important phenomenon, an imbalance to be taken into account, often encountered and with a major impact on the economies of various countries. Even if the consequences of this phenomenon may differ from one period to another, depending on the economic policies promoted, as well as the capacity and ability of governments to control the process, one aspect is certain, namely that macroeconomic levels lead to general imbalances in the national economy, with multiple economic and social effects. The purpose of this article is to analyze the inflationary process, its forms, identify measures to combat and study the dynamics of this phenomenon in Romania and the Euro Area.
\end{abstract}

(C) 2020 EAI. All rights reserved.

\section{Introduction}

Inflation is a complex, monetary phenomenon that, to varying degrees and depending on certain factors, produces effects on national economies. Broadly speaking, it is characterized by an increase in prices at the same time as a decrease in the purchasing money power.

It is emphasized in the literature that inflation has a long history, and the inflationary process manifested itself long before economic science appeared. At the same time, this phenomenon has evolved over the centuries, but it should be noted that this has occurred with unequal intensities and changes in meaning. And due to the fact that there were periods in which the process took place with significant intensities and effects, it was considered, rightly so, "the disorder of disorder in economic life. [2]

\section{Definition and forms of inflation}

In specialized literature inflation it is considered generated by a surplus, a increase in demand for goods and services, and the most important is that the economy can not answer. A slow rise in prices, followed by a chronicization of prices as an effect of maintaining the initial momentum - involve key features of inflation. [3]

Other authors state that we will find ourselves in the face of an abnormal monetary situation called inflation, every time the currency is created and put into circulation on the market, in the context in which the real needs of production, exchange of goods are exceeded, thus, it is considered that in these moments we will find ourselves in front of an abnormal, artificial monetary situation, called inflation.[5]

According to other specialists, inflation is a situation in which "the money supply exceeds the needs of the economy, which means a weakening of the purchasing money power.". [4]. Depending on the causes that determine the occurrence of inflation, there are several forms of this phenomenon.

The first criterion, the intensity and duration of inflation, highlights the following forms of this complex phenomenon:

- creeping inflation or is also called quiet inflation - which is characterized by an acceleration of prices to a level of about 3-4\% per year. This type of inflation usually generates non-inflationary economic growth and is specific to highly developed countries.

- moderate inflation - in this situation prices are generally growing at an average rate of up to $6 \%$. A characteristic of this type of inflation is the fact that it represents a performance criterion in the case of poorly developed and transition countries, and in developed countries, moderate inflation is manifested only sometimes.

- rapid inflation - is characterized by the fact that the value of the annual inflation rate registers a level of up to $10 \%$; 
- galloping inflation - given that prices rise above the level of $15 \%$ per year, having a strong destabilizing effect, and can produce, in a very short period, even a doubling of prices, a significant depreciation of the national currency, a sharp decline in purchasing power.

- hyperinflation - the situation in which there is an increase in consumer prices, above the level of $50 \%$, in a month.

forms:

Another classification is the one according to inflationary expectations, distinguishing the following

- anticipated inflation or expected inflation - the situation in which this phenomenon will be seen, expected by all economic actors who will take measures not to be affected by its effects and adapt their behavior to the state, value and rate of the inflationary process in the future;

- Unanticipated inflation - is characterized by the fact that it exceeds the production capacity of the economic entity, and not being forecasted, the possibility of previous protection is also canceled, taking by surprise the business environment, consumers, various organizations.

The measurement of inflation, intensity and evolution of this phenomenon is based on an index of consumer prices which calculates and measures the level of generalized increase in prices while there is a decrease in the purchasing money power.

Identifying and analyzing the effects of inflation is not easy due to the fact that it is a rather complex economic and social phenomenon characterized by many causes and that despite extensive and multiple research on it, remains one of the most controversial issues in the contemporary world, persistent and almost omnipresent in the current period, virtually all countries.

During the intense manifestation period of the inflationary phenomenon, there are important structural changes in the national economy, both annually and even monthly within the same areas or countries, which can be determined by inflation itself, as well as by a series of economic measures that generated and fueled this inflationary process.

In the case of most modern states, with market economy, characterized by the existence of the inflationary phenomenon, there is a need to take measures to combat or at least improve the effects of this phenomenon, because of the multiple negative consequences on economic development but on society in general, combating the negative impact of inflation being one of the key objectives of macroeconomic policies.

The fight against the inflation effects must involve a permanent, long-term action to achieve good and sustainable results, as it is known that an aggressive short-term policy will also have short-term consequences, affecting the production use factors, accentuating and fueling an economic decline in the future.

In the fight against inflation, indirect economic policy measures are used with an impact on the size and dynamics of aggregate demand, but also on the size and dynamics of aggregate supply.

Regarding the policies oriented towards the control of the aggregate demand, either the instruments of the fiscal policy or the instruments of the monetary policy are used.

In the first case, two main levers are used, namely: reducing government spending and raising taxes, in this way the money supply for consumption can be reduced.

If we refer to monetary policy, due to the fact that inflation is a predominantly monetary phenomenon, then the measures taken in this area are more deeply argued. Thus, it focuses on decreasing the money supply, or on lowering the interest rate. This encourages savings to the detriment of using credit. The literature insists that inflation is a predominantly monetary phenomenon. This explains the fact that the measures that come from such a direction are more numerous and more thoroughly argued.

Recently, in university and political circles in developed countries, the idea that a higher inflation target (approx. 4\%) is, in fact, desirable, that gives central banks more leeway to reduce interest rates in the event of a future recession. [1]

\section{The inflation rate in Romania and Euro Area}

If we refer to inflation in Romania, we can say that it was started after 1990 with the first price liberalization. Basically, with the transition from centrally planned to market economy, inflationary phenomenon in Romania, registered high values. Equally important is that after 2000, Romania aimed to join the European Union, which influenced the entire programmatic framework of medium-term economic policy, which was thus conceived and articulated as a training for integration, bringing its contribution to creating a functioning market economy compatible with the principles, rules, mechanisms and institutions of the European Union.[6] In the period that followed, the National Bank of Romania adopted a new monetary policy strategy, namely that of targeting inflation. 
Figure 2. The evolution of the annual inflation rate in Romania, during the period 2000-2019, \%

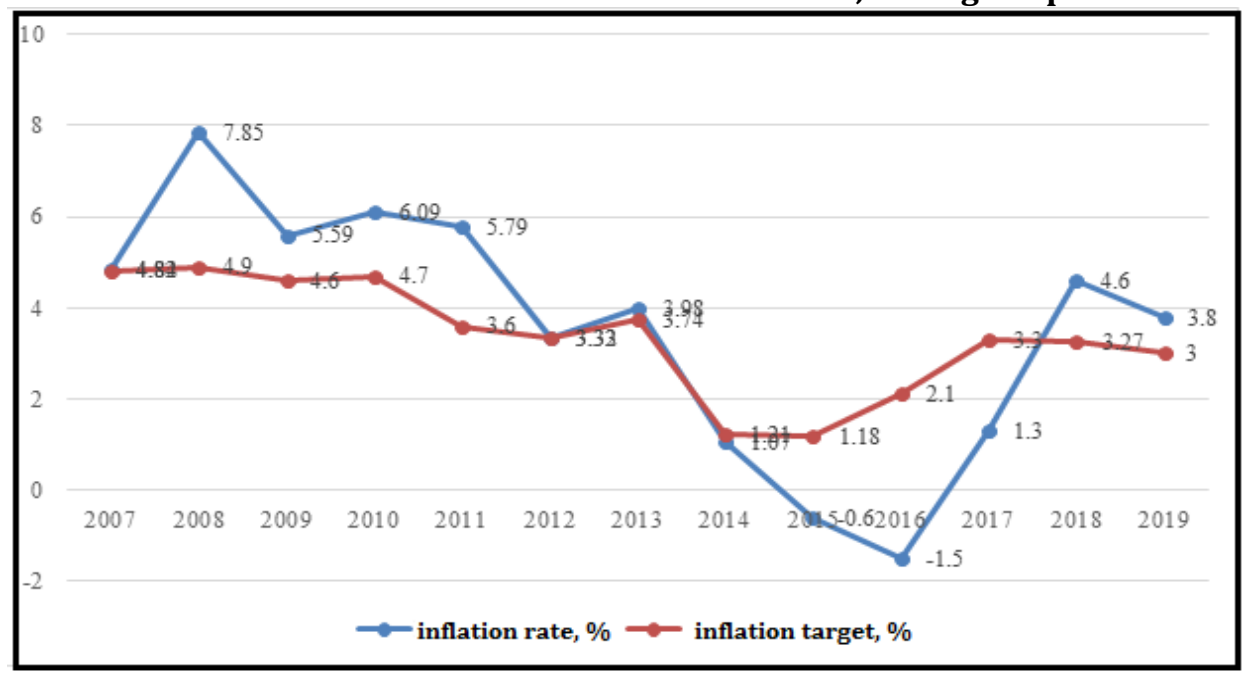

Source: Romanian National Institute of Statistics

Between 2007-2019 inflation rate in Romania had a fluctuating evolution. If in 2007 the inflation rate was $4.83 \%$, in 2008 , it increased to $7.85 \%$. In the period that followed, the trend was downward, reaching $3.33 \%$ in 2012. During 2013, the indicator recorded a slight increase of up to $3.98 \%$, after which it decreased continuously, and in the period 2015-2016 it entered negative territory. Thus, in 2016 the lowest value of the analyzed period was registered, namely 1.5\%. The following period was marked by an increase in the inflation rate until 2018 when the level of $4.6 \%$ was registered, after which a decrease was recorded up to $3.8 \%$ in 2019.

In the euro area, consumer price inflation is measured by the harmonized index of consumer prices. Thus, this indicator measures the change over time in the prices of consumer goods and services purchased, used or paid for by euro area households over a period of time.

Figure 1. Evolution of the inflation rate in the Euro Area in the period 2012-2020, \%

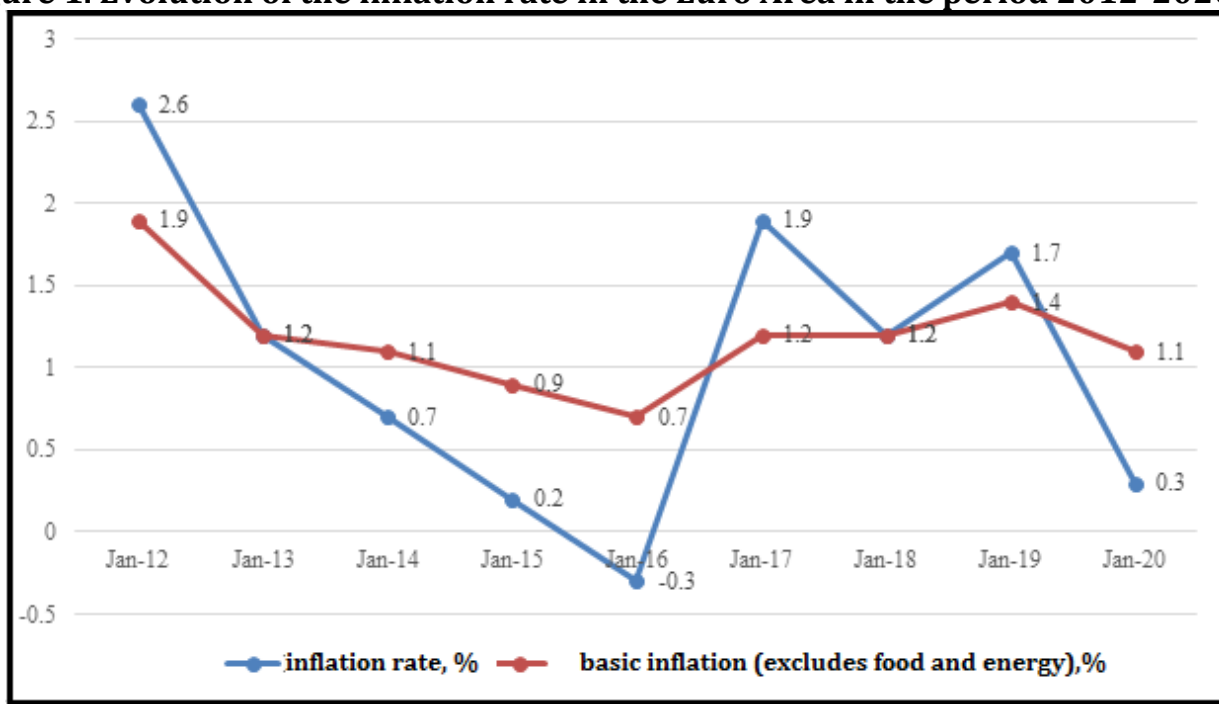

Source: European Central Bank

As can be seen in Figure 2, the inflation rate had a downward trend starting with 2012 when it recorded a value of $2.6 \%$ and until 2016 when it recorded a negative value of $-0.3 \%$. In the aftermath, the indicator grew, reaching $1.9 \%$ in 2017. Subsequently, after a decrease to the level of $1.2 \%$, it experienced an increase again until 2019. It should be noted that the year 2020 was marked by a decrease in the inflation rate to the level of $0.3 \%$.

\section{Conclusions}

It can be concluded that one of the most drastic phenomena present in a country's economy, with profound effects on it and which is characterized by the process of widespread price increases and declining purchasing money power, is represented by inflation. 
Being first of all a monetary process, inflation is in an essential connection with the mass of money in circulation, money being in this key variable equation, and in these conditions, the nature of this phenomenon is characterized and is closely related to the evolution over time of the historical forms that money has taken on.

In the modern economy conditions, inflation cannot manifest itself in the absence of money and is defined as a structural imbalance, which reflects the fact that in the economy there is a supply of money in circulation that exceeds its real needs. The phenomenon that is triggered in this way, leads to the devaluation of the currency, a decrease in the value of money and very importantly, there is at the same time a general increase in prices. These are the significant effects of inflation.

In addition, the effectiveness of monetary, fiscal, legislative policies that are applied and promoted over time by governments as well as by the Central Bank of any country, at the end of a fiscal year, are also assessed with the help of inflation, which reflects whether respectively are efficiently coordinated so as to generate a favorable situation at macroeconomic level and a stability of consumer prices.

Regarding Romania, with the transition to the market economy, there was an explosion of prices, especially in the population consumer goods. The intensity and duration of the inflationary process in Romania proved to be above average, and to this aspect contributed causes that are related to the objective conditions of economy functioning but also to the nature of the economic policy that has been promoted over time.

\section{References}

1. Cerna S., Se întoarce inflația?, Universitatea de Vest din Timișoara, 2018, pag.5, available at: http://www.contributors.ro/economie/seintoarce-inflatia, accesat la 19.05.2020

2. Ciumara M., Ciutacu., Inflația în România, Editura Expert, București, 2003, pag.11

3. Keynes, J.M., Teoria generală a folosirii mâinii de lucru, dobânzii și banilor, Editura Stiintifică, București,1970, pag.375

4. Kiriţescu, C., Monedă. Mica enciclopedie, Editura Știintifică și Enciclopedică, București, 1982, pag. 190

5. Slăvescu, V., Curs de monedă, credit, schimb, Editura Scrisul Românesc, Craiova, 1932, pag. 183

6. Camera Deputatilor, Strategia naţională de dezvoltare a României pe termen mediu 2000-2004 din 16 martie 2000 , available at: http://www.cdep.ro/pdfs/strategie.pdf 